\title{
Abstract
}

\section{Chinese and Western Investments in Africa: A Comparative Analysis}

\section{Peterson Nnajiofor}

IDEA Research Center, University of Lorraine, Metz, France

peterson.nnajiofor@univ-lorraine.fr

Chinese investments in African countries have increased massively in the last two decades.

Critics have been vociferous for or against the Afro-Chinese relationship depending on their convictions making it a bit difficult to have an objective analysis on the issue.

African nations and their leaders have repeatedly shown preference for Western culture and civilization due to or despite their respective and common historical experiences.

When given the option, African states tended to embrace Western companies and businesses. This can be seen in the larger majority of Western businesses established in the continent compared to those from other parts of the world.

Foreign direct investments into Africa have also been traditionally from the West. But this preference for the West at least since the age of independence has not yielded the anticipated results. And this is the main reason why the Chinese are seen as an alternative today. Using the most recent research and data on this topic, this paper endeavors to analyze the nascent Chinese policies and investments in Africa comparing and contrasting their successes and failures compared to those of Western countries.

Keywords: Chinese Africa investments, African economy, Chinese FDI, South-South trade relations, Afro-Chinese economic development, Globalization. 


\section{Chinese and Western Investments in Africa: A Comparative Analysis}

"/.../ All the money in this world is either Red or Blue. I do not have my own Green money, so where can I get some from? I am not taking a cold war position. All I want is money to build it." (Julius Nyerere. July 3, 1965)

Critics have been vociferous for and against the Afro-Chinese relationship depending on their convictions rendering it a bit difficult to have an objective analysis on the issue. African nations and their leaders have repeatedly shown preference for Western culture and civilization due to or despite their respective and communal historical experiences. When given the option, African states tended to embrace Western companies and businesses. This can be seen in the larger majority of Western businesses established in the continent compared to those from other parts of the world. Foreign direct investments into Africa have also been traditionally from the West. But this preference for the West at least since the age of independence has not yielded the anticipated results. And this is the main reason why in a globalized world economy, the Chinese are seen as an alternative today.

The above citation by former President of Tanzania Julius Nyerere while talking about the TanZam or Tazara (Tanzania Zambia Railway) construction project most aptly renders, from the African perspective, one of the main reasons underlying the relationship between African countries and the People's Republic of China. The main driving force of this relationship has been mainly the availability of financial access for the much-needed infrastructural and socioeconomic development in Africa on the part of African governments. And access to strategic raw materials necessary for Chinese factories as well as markets for Chinese goods on the part of increasingly capitalist Chinese government and companies. Chinese investments in Africa are not charity. The objective is to make profits and establish influence though the approach largely differs from that of the West. 
However, it is noteworthy that even Julius Nyerere and the Zambians first approached the British and other western countries for the Tazara project. The Chinese were accepted for the project after all other options had been exhausted (Altofer-Ong 2009).

In the past, especially during the period of the Tazara project, there were still the underlying effects of the cold war ideological rivalry between the West and the socialist and communist powers symbolically represented by China. The main aim of the Chinese government during that period was geared more towards the spreading of the communist ideology and influence than to making profits. Today, although the aspect of influence is still a factor in the Chinese engagements in Africa and other parts of the world, it is no more the main driving force. Making money and profits in this new phase of globalization in line with the new state-driven economic model of the Chinese today, has increasingly replaced it.

There is still a lot to be criticized about the newfound economic influence of the Chinese in Africa, but these criticisms need to be tempered with objectiveness. In this paper, we will try to do this by comparing Chinese activities in Africa to that of the West. Different aspects of the Africa-Chinese relationship like the direct and indirect impacts it has on the population will be treated too. A comparison of the relationship between the Chinese and countries from other continents will also be analysed in order to see how they fare generally.

\section{Comparative Analysis of the Strategies of U.S. /the West and China in Africa}

Comparing the strategies of the U.S. and other Western countries in Africa to that of the Chinese facilitates our understanding of the issues at stake in the Africa-China relationship. Since the arrival of the Portuguese followed by the Slave Trade, colonization and independence, Western nations have been the dominating power in all aspects of life in Africa. Western influence is noticeable in the politics, religion, economy, technology, and languages of Africans to mention but a few. This influence has made Africans to look towards the West as reference and model for most things. This is not limited to Africa but is more prevalent there than in other parts of 
the world. This reference model mentality makes African countries to turn to the West for answers to most of their developmental and at times social needs. The West has for long taken this for granted. It considers Africa as an acquired area of influence and Africans as "students" who need guidance from their "master".

This is flagrant in the type of treatment received by many African nations from Westerndominated financial institutions. Western aid, grant, loans and contracts tend to come with conditions that most times deny any sort of independence of choice to African countries. The drive for privatization of public corporations and the imposition of structural adjustment programs by the West on most indebted countries of Africa as preliminary conditions for debt alleviation is a vivid example. Moyo $(2010,39)$ captures the futility of these aid and loan programs when she states that:

"Donors have tended to tie aid in three ways. First, it is often tied to procurement. Countries that take aid have to spend it on specific goods and services which originated from the donor countries, or a group selected by them. This extends to staff as well: donors employ their own citizens even when suitable candidates for the job exist in the poor country. Second, the donor can reserve the right to preselect the sector and/or project that their aid would support. Third, aid flows only as long as the recipient country agrees to a set of economic and political policies."

She went on to explain how aid was exploited by donor countries to reduce civil service, privatize national industries and remove trade barriers. In short, Western aid in all its forms despite its conditions never worked in Africa. Bribery and corruption, dictatorship, insecurity and bad governance did not abate, on the contrary. Up to 85 per cent of aid money were found to have been diverted to unproductive projects (Moyo, 2010, 39) and often simply stolen by corrupt officials. The conditionalities were of little effect and sometimes, the socio-political aspects like the establishment of democracy and curbing of corruption, are simply ignored by 
donor as well as receiving parties. It appears that no link can be established between a country's reform effort or fulfilment of conditionality and the disbursement rate of aids funds (Svensson, 2000).

The Chinese on the other hand have consistently insisted on neutrality and non-interference in the internal affairs of countries where they operate. This makes the Chinese alternative more attractive for African countries because there is a feeling of respect and equality that facilitates interactions. The activities of the Chinese government notably through the aegis of the Forum on China-Africa Cooperation (FOCAC) enhances this feeling of respect, equality and seriousness for Africans. Anette Nijs, former Dutch junior cabinet minister also arrived at the same conclusion. (Nijs, 2008; Soumare et al, 2016).

The main criticism by the West against this non-interference attitude of the Chinese is that it encourages corruption and helps in propping up corrupt leaders and dictators. It is however clear that the approach of the West has never abated nor stopped corruption. The most corrupt African leaders and dictators like Mobutu Sese-Seko of Congo, Omar Bongo of Gabon, Gnassimgbe Eyadema of Togo, Sani Abacha of Nigeria, Hosni Mubarak of Egypt, Ben Ali of Tunisia, to mention but a few, all saw their activities flourish and enriched themselves under the aegis and at times active participation of Western powers.

The ethics and moral aspects of doing business in Africa held as sacred in public by Western powers do not pass the test of any serious scrutiny of the actions of Western corporations operating in the continent. The Chinese are said to be immoral and unethical in their dealings in Africa. The following extract from Hillary Clinton's speech is an example of what is now commonly known as China bashing:

"Well, our view is that over the long run, investments in Africa should be sustainable and for the benefit of the African people. It is easy - and we saw that during colonial times - it is easy to come in, take out natural resources, pay off leaders, and leave. And when you 
leave, you don't leave much behind for the people who are there. You don't improve the standard of living. You don't create a ladder of opportunity. We don't want to see a new colonialism in Africa. We want, when people come to Africa and make investments, we want them to do well, but we also want them to do good. We don't want them to undermine good governance. We don't want them to basically deal with just the top elites and, frankly, too often pay for their concessions or their opportunities to invest" (Clinton, June 11, 2011). The activities of American and European companies in Africa and other parts of the world tend to go contrary to the professed wishes of Ms. Clinton. Her criticism of the Chinese here could easily be redirected to American and other Western nations and companies.

It is important to note that the main aim of Westerners that first ventured into Africa was to do "business" and to enrich themselves and they succeeded. Most of the nations of Africa that were colonized by Westerners had their wealth and treasures looted. This looting is still going on in the oil and mineral rich nations of Africa. It is organized and executed by Western corporations in the Niger Delta of Nigeria, in the mines of the Democratic Republic of Congo, in the uranium fields of Niger and the list goes on. Western corporations backed by their governments do not hesitate over ethics and morals when making money is concerned. Thus, criticising China appears at least partial and dishonest seen from this angle.

Symbolically, it is interesting to observe that the first important transaction between the Chinese and African governments resulted in the successful construction of one of the most difficult projects ever carried out in Africa; the Tanzam project. This was done at a price that was substantially below that proposed by American companies. The Chinese carried out the project despite the fact that they were not rich at the time.

The growth of China's economy in the last four decades has made a lot of observers to overlook the fact that China is still a developing country. However, this fact does not stop China from 
investing billions in Africa. A substantial part of these investments is channelled to infrastructure projects, which most observers agree are terribly wanting in Africa.

Mayaki (2019) noted that "only 38\% of the African population has access to electricity, the penetration rate for internet is less than $10 \%$ while only a quarter of Africa's road network is paved. Studies have shown that poor road, rail and port facilities add $30 \%$ to $40 \%$ to the costs of goods traded among African countries, thus adversely affecting the private sector development and the flow of foreign direct investment (FDI).”

China completed $\$ 40.38$ billion worth of infrastructural projects in Africa in 2012 and has continued since in several African countries. Western actors in this sector never invested much in African infrastructure that was not meant for their own purposes, even though everybody is aware that it is one of the most important elements to lift the continent out of poverty. Even that little that was invested tended to be siphoned by corrupt officials and their Western facilitators in offshore tax havens and other capitals of illicit fund transfers and depots. The corrupt African leaders and their Western associates have made white elephant projects a hallmark of Africa.

The Chinese approach to this problem of infrastructure on the other hand has been rather stellar compared to the West. The Chinese are not just investing heavily in African infrastructure but are actually executing the projects successfully at considerably lower costs and at or ahead of schedule (Xiao Ye, 2012). This approach has proved more effective in developing the muchneeded infrastructure in Africa. Foster, Vivien, et al. (2009) in their World Bank study on this observed that:

"The advent of China and other non-OECD players as major financiers presents itself as a hopeful trend for Africa, given the magnitude of its infrastructure deficit. The aid provided by the emerging financiers is unprecedented in scale and in its focus on large-scale infrastructure projects. With new actors and new modalities, there is a learning process ahead for borrowers and financiers alike. The key challenges for African governments will be how 
to make the best strategic use of all external sources of infrastructure funding, including those of emerging financiers."

Some African observers have also noted the importance of Chinese FDI and most importantly, the seriousness and rapidity of their infrastructural projects in Africa (Kobo 2013).

\section{Chinese Investments and Aid in Mineral Rich Countries of Africa}

Another recurring criticism is that the Chinese are looting Africa, investing in only oil and mineral-rich countries because they need the raw materials from these nations to feed Chinese factories. Results of surveys carried out by Kolstad \& Wiig (2011) shows that Chinese investments in Africa are actually focused more on resource-rich countries. This leads to accusations of neo-colonization and exploitation. Once again, when compared to OECD and other investors active in Africa, there appears to be not much difference in the approach towards investment decisions.

The major part of the OECD investments and aid is directed to mineral rich countries like South Africa, Republic Democratic of Congo, Angola, and Nigeria. Strategic resources like petroleum, coltan, uranium, gold, copper, diamond, to mention but a few are all dominated by Western companies today in Africa. It would appear strange to expect increasingly capitalistdriven China to act differently. Chinese businesses, even if they are still not comparable to Western corporations are capitalist organisations, albeit with Chinese characteristics as Yasheng Huang (2011) would say, motivated by profit maximization. Thus, they invest in nations where they expect returns on their investments.

It is important to note that Chinese imports from these mineral-rich countries may be on the increase but is still low compared to that of Western nations. A 2012 IMF study showed that Chinese Foreign Direct Investment (FDI) in the mining sector in the whole of Africa represents only $29 \%$ of total Chinese investments in Africa (The Economist, September 21, 2013). This means that over $70 \%$ are channelled to other areas mainly in construction, retail and trade, 
services and manufacturing. In the same vein, Soumaré et al (2016) noted that Chinese presence in Africa, with the exception of South Africa, "tended to be greater in almost all African countries with a more or less equal allocation of its investments" whereas OECD countries "seem to invest heavily in a few countries in Northern and Southern Africa, and in big oil exporting economies."

\section{Hiring Practices}

Chinese companies have been repeatedly criticized for not employing or employing a little number of Africans in the projects that they work on in Africa or in their companies (The Economist, April 20, 2011). A symbolic example that is mostly cited is the construction of the African Union building in Addis-Abeba, Ethiopia, which was given as a gift by China to the African Union. Press reports alleged that the project was executed by imported Chinese labour. In a continent with high level of unemployment especially among the youth, this is a very important issue and need to be addressed. However, investigations by Deborah Brautigam of John Hopkins University showed that there was a ratio of 1:1 (Chinese /African workers) in the workforce on that project, which could be explained by the importance of the project for the Chinese and the deadline that needed to be met. But most importantly were the figures that she gave for the majority of Chinese projects in Africa, which is around 20 Chinese to 80 African workers (Brautigam 2012). The Chinese are in reality creating jobs in areas where unemployment is rampant. Data on Chinese labour practices were analysed in depth by Brautigam and they dissipate some of the concerns surrounding this issue.

When compared to the practices of Western actors in Africa, there is not much difference. As mentioned earlier above (Moyo 2008), Western governments and companies often impose conditionalities of employment on projects that they run in Africa giving preference to their companies and citizens even in situations where qualified candidates are readily available in the African nation concerned. 
Having seen all these, it is important to look at the effects that the different approaches have on the people and economies of African states.

\section{Concrete and visible projects}

The African population overwhelmingly approves of the results of the relationship and the projects carried out by the Chinese. A 2015 Pew Global attitudes survey found that African respondents "had a significantly more positive view of China" at 70\% compared to respondents from other parts of the world: $41 \%$ in Europe, $57 \%$ in Asia and Latin America respectively (Chen et al 2015). This may be due mainly to the fact that Africans can see the immediate results of the relationship with China in the Chinese projects which are generally of good quality and at a substantially lower price compared to those of Western companies, and the fact that the projects are delivered on time. Moreover, the effects of these projects and programs are concrete and visible. The roads, bridges, schools, hospitals, stadiums, official buildings, railways, telecommunication infrastructure, etc. are immediately available for use and positively participate in ameliorating the lives of the people.

It is also important not to underestimate Chinese FDI in the retail and trade sectors and the importance of Chinese products, generally cheaper than their Western counterparts. In addition to these is the development of several special economic zones that are geared towards the development of trade and industry and welcomed as a channel of technology transfer in Africa. These zones are gradually creating jobs and helping in the economic growth that is being witnessed in some African countries.

The following six special economic zones have been setup by the PRC in collaboration with African governments and many more are in the making in different parts of the continent: 
1. Chambishi, Zambia - specializing in the production and processing of copper and copper related industries.

2. Lusaka, Zambia - specializing in the production of garments, food, appliances, tobacco and electronics.

3. Jinfei, Mauritius - specializing in the production of manufactured goods (textiles, garments, machinery, high-tech), trade, tourism and finance.

4. Oriental, Ethiopia - specializing in the production of electrical machinery, construction materials, steel and metallurgy.

5. Ogun, Nigeria, - specializing in the production of construction materials, ceramics, ironware, furniture, wood processing, medicine, and computers.

6. Lekki, Nigeria - specializing in the production of transportation equipment, textiles, home appliances, telecommunications, and light industry.

The strategic positions of these zones and the diversity of the economic sectors involved make them to appear as very important elements in the economic development of Africa.

At this point, it is important to note that the relationship between China and Africa is mainly based on the special circumstances that the two parties found themselves in and the need to make the most of the available opportunities. The Chinese need the raw materials from Africa and also the small but growing market of the continent. Africans need Chinese expertise, relatively cheap labour and cheap products for the sustenance and improvement of their economies. Today, China, despite its shortcomings, appears to be the only credible alternative for African governments. Criticizing the relationship is not going to change much in as much as other viable alternatives are wanting. It is interesting to observe that even those criticizing 
the Africa-Chinese relations are deeply involved with the Chinese in their own economies as could be seen in the following paragraph.

\section{Comparable situations}

The Chinese are not just investing in Africa alone. Their investments can be seen in the economies of different countries and in different regions of the world. The first recipients of Chinese FDI are Asian nations. There are also substantial Chinese investments in the developed economies of North America and Europe.

Increasingly, the Chinese are investing in European economies. The cases of Greece and Spain come to mind rapidly but Chinese investments are not limited to those two countries. Chinese FDI touches a lot of European countries and has been on a rapid increase in the last decade. In France, as of 2013, commercial agreements of $\$ 22.8$ billion were signed with the Chinese in areas such as nuclear energy, air transportation and telecommunications. As of 2019, according to the French Foreign Ministry, "Chinese investment in France has grown significantly in recent years ( $€ 6$ billion in FDI stock). A total of 700 subsidiaries of Chinese and Hong Kong companies are set up in France and employ 45,000 people (Invest in France, June 13, 2013).”

These investments are sought after and welcomed by European governments especially since the last financial crises. The latest EU legislative measures to check foreign investments in strategic sectors is more of a political action than an economic one as the Italian government signing up to the Belt and Road Initiative despite criticisms shows.

China's trade ties with Germany is believed to be the major element in the recent German sturdy economic growth compared to other European economies and underlies German support for the Chinese in European negotiations. 
In a globalized world economy, China's investments are equally increasing in other regions of the world. Billions of dollars are being invested by Chinese companies in the United States, in Canada and Latin America as well as in Australia. The governments of these countries are generally enthusiastic to receive those Chinese investments that they believe would boost their economies despite the diatribe of politicians aimed at winning populist votes.

\section{Conclusion}

It is important to note that unlike African countries, the majority of the countries mentioned above have other sources of FDI and the majority of them can already boast of developed economies. But all these notwithstanding, they still seek more Chinese investments. Most African countries, on the contrary do not necessarily have other sources of FDI except for the mineral-rich ones and many of them do not even have functioning economies. Fortunately, one might be tempted to say, we are basically in a new phase of globalization in which FDI capital is no longer the privilege of the West alone. New and increasingly dynamic players are on the field and this means more choices for the receiving countries like those of Africa. Asking them to refuse Chinese aid and FDI appears unconscionable. African governments, politicians and the elite should devise strategies of making the best of the Chinese opportunities. Putting conditions and restrictions in order to regulate the way the relationship with China functions would be a good way of mitigating the possible negative outcomes of the relationship. Some countries like Angola have already started doing this by imposing percentages on the equity ownership and the number of Chinese workers allowed on projects with the Chinese. These are possible ways of ensuring that the relationship is not overly lopsided. In conclusion, one may want to look at the opinion of the people concerned, the population. Looking for or believing that there is and should be no dominant party in the Africa-China relationship appears naïve. He who pays the fiddler calls the tune. 


\section{References}

Altofer-Ong, Alicia. 2009. Tanzanian 'Freedom' and Chinese 'Friendship' in 1965: laying the tracks for the TanZam rail link. LSE Ideas, PhD Theses. Accessed January 13, 2020

https://web.archive.org/web/20121003005918/http://www2.lse.ac.uk/IDEAS/publications/ workingPapers/altorferOng.pdf

Asongu S.A. and Aminkeng G.A.A. 2013. The Economic Consequences of China-Africa

Relations: Debunking Myths in the Debate, AGDI Working Paper, WP/13/020, 2013.

Brautigam, Deborah. 2011. The Dragon’s Gift, Oxford: Oxford University Press.

Brautigam, Deborah. 2013. "Chinese Workers in Africa Anecdotes. China Africa Real Story" Accessed 12 December 2013. http://www.chinaafricarealstory.com/p/chinese-workers-inafrica-anecdotes.html Current link: http://www.sais-cari.org/data-chinese-workers-in-africa

Chen, Wenjie, Dollar, David and Tang Heiwai. 2015. "Why is China investing in Africa? Evidence from the firm level. Accessed January 14, 2020 https://www.brookings.edu/wpcontent/uploads/2016/06/Why-is-China-investing-in-Africa.pdf

CTVNews, Clinton warns Africa of 'new colonialism'. Accessed January 13, 2020 https://www.ctvnews.ca/clinton-warns-africa-of-new-colonialism-1.656101

Foster, Vivien, William Butterfield, Chuan Chen, and Nataliya Pushak, 2009, Building Bridges, China's Growing Role as Infrastructure Financier for Sub-Saharan Africa, the World Bank.

France Diplomatie, "France and China Bilateral Relations" (2019). Accessed 19 January 2020. https://www.diplomatie.gouv.fr/en/country-files/china/france-and-china/

Huang, Yasheng. 2008. Capitalism with Chinese Characteristics: Entrepreneurship and the State. Cambridge: Cambridge UP. Print. 
Invest in France Agency, Chinese in investments in France continues to grow. Accessed June 7, 2013. http://www.invest-in-france.org/us/news/china-investments-in-france-continue-togrow.html

Kobo, Ousman Murzik. 2013. A New World Order? Africa and China. Origins, vol. 6, issue 8 - May 2013. Accessed 13 January 2020. https://origins.osu.edu/article/new-world-orderafrica-and-china/page/0/2

Kolstad, I., \& Wiig, A., 2011. "Better the Devil You Know? Chinese Foreign Direct Investment in Africa”, Journal of African Business, 12(2), 31-50.

Le Point, ${ }^{1}$ Bordelais : 3 châteaux passent sous pavillon chinois. Accessed 30 January 2020.

http://www.lepoint.fr/economie/la-chine-continue-de-placer-ses-pions-en-france-28-05-20131673035_28.php?goback=\%2Egmr_2870642\%2Egde_2870642_member_245037986

Mawdsley, E. (2008). "Fu Manchu versus Dr Livingstone in the Dark Continent? How British broadsheet newspapers represent China, Africa and the West”, Political Geography, 27, pp. $509-529$

Mayaki Ibrahim. 2019. Accessed 13 January 2020. https://www.un.org/africarenewal/webfeatures/why-infrastructure-development-africa-matters

Mihalakas, Nasos, China's investments in Europe: to save or not to save the Euro. The Magazine for International Business and Diplomacy, Issue No. 3, March 2011.

Moyo, Dambisa. 2009. Dead Aid. New York: Farra, Straus and Giroux.

Nijs, Annette. In The Economic Consequences of China-Africa Relations: Debunking Myths in the Debate, A G D I Working Paper WP/13/020, 2013, pp. 10-11.

Nyerere, Julius. PRO, DO183/730, From Dar es Salaam to CRO, No. 1089, 3 July 1965. Alicia Altofer-Ong Tanzanian 'Freedom' and Chinese 'Friendship' in 1965: laying the tracks for 
the TanZam rail link. LSE P. 22 Accessed 13 November 2013. http://www.lse.ac.uk/IDEAS/publications/workingPapers/altorferOng.pdf

Soumaré, Issouf, Gohou, Gaston and Kouadio Hugues (2016) Comparative study of the characteristics of FDI from China to Africa versus developed countries, Transnational Corporations Review, 8:3, 165 177, DOI: 10.1080/19186444.2016.1233715. Accessed 30 January 2020. https://doi.org/10.1080/19186444.2016.1233715

“China and Africa, Little to Fear but Fear Itself." The Economist, September 21, 2013.

"Africans are asking whether China is making their lunch or eating it." The Economist, April 20, 2011

Svensson, Jakob, 2000. "When is foreign aid policy credible? Aid dependence and conditionality," Journal of Development Economics, Elsevier, vol. 61(1), pages 61-84, February.

Xiao Ye, (2010) A Path to Mutual Prosperity? The trade and investment between China and Africa. Accessed 30 January 2020. https://www.afdb.org/fr/documents/document/aec-2010a-path-to-mutual-prosperity-the-trade-and-investment-between-china-and-africa-21840 